\title{
HUBUNGAN ANTARA KONTROL DIRI DENGAN KENAKALAN REMAJA DI KELURAHAN MABAR HILIR
}

\author{
Nini Sriwahyuni, S.Psi. M.Pd, M.Psi \\ Fakultas Psikologi \\ Universitas Medan Area
}

\begin{abstract}
Abstrak
Tujuan penelitian ini adalah untuk melihat hubungan antara kontrol diri dengan kenakalan pada remaja di Kelurahan Mabar Hilir. Jenis penelitian ini adalah korelasional dengan menggunakan instrument skala kontrol diri yang disusun dari aspek-aspek kontrol diri menurut Averilln dan skala kenakalan remaja yang disusun dari aspek-aspek kenalakan remaja menurut Jansen. Data penelitian ini diambil dari 40 sampel yang dianalisis menggunakan rumus product moment dari Carl Person. Berdasarkan analisis data maka diperoleh hasil bahwa terdapat hubungan negatif yang signifikan antara kontrol diri dengan kenakalan remaja dengan $r_{x y}=0.421$ Sig 0.04, p < 0.05. 2) dengan sumbangan 17.7\% dari kontrol Diri terhadap kenakalan remaja. Hal ini berarti masih ada $82.3 \%$ faktor lain yang mempengaruhi kenakalan remaja, dintaranya identitas, usia, jenis kelamin, harapan terhadap pendidikan dan nilai-nilai di sekolah, proses keluarga, pemgaruh teman sebaya, kelas sosial ekonomi dan kualitas lingkungan sekitar tempat tinggal.
\end{abstract}

Kata kunci : Kontrol Diri, Kenakalan Remaja

\section{PENDAHULUAN}

Masalah kenakalan remaja dewasa ini telah menjadi suatu permasalahan yang serba kompleks di berbagai tempat baik di kota-kota besar maupun kota-kota kecil. Di Indonesia sendiri kenakalan remaja merupakan permasalahan sosial yang menunjukan perkembangan yang kurang sehat terutama dalam lingkungan hidup masyarakat yang bertempat tinggal di kota-kota besar, sehingga menimbulkan problema-problema yang cukup rumit bagi keluarga, dan masyarakat.

Hampir setiap kasus kenakalan remaja selalu kita temukan di mediamedia massa, dimana sering terjadi di kota-kota besar seperti, Jakarta, Surabaya dan Medan. Salah satu wujud dari kenakalan remaja adalah tawuran yang di lakukan oleh para pelajar atau remaja. Departemen Sosial memberikan estimasi bahwa jumlah pada tahun 2004 diperkirakan jumlah penyalahgunaan narkotika yang sebagian besar adalah remaja, mencapai angka sampai 3,6 juta orang setara dengan $1,5 \%$ penduduk Indonesia

(http://internasional.kompas.com/read/20 09/02/05/2127257//Anak.Nakal.Salah.Or angtuanya).

Di kota Medan sendiri kenakalan remaja juga terjadi pada beberapa remaja. Bentuk kenakalan remaja yang ditemukan pada tahun 2009 yaitu kebutkebutan di jalan sebanyak 95 orang, yang menewaskan 10 remaja. Perilaku ugalugalan, berandalan, urakan, yang 
mengacaukan ketentraman sekitar juga dilakukan pada 105 remaja di Kota Medan ini. Perkelahian antar gang, antar kelompok, antar sekolah, antar suku (tawuran) sebanyak 98 orang dan membawa 34 korban luka-luka. (http://www.wikimu.com/News/Display News.aspx?id-12915/)】.

Adapun kenakalan-kenakalan yang dilakukan oleh para remaja di kelurahan Mabar Hilir adalah berkelahi, bermain judi, mabuk-mabukan, membolos, merokok, kebut-kebutan dijalan raya, mencuri serta pada taraf mencoba memakai obat-obatan terlarang dan melakukan perbuatan yang menjurus pada perbuatan kriminal atau perbuatan yang melanggar hukum.

Hal ini sesuai dengan pernyataan Baumeister, Heatherton \& Tice (1994) yaitu seseorang kehilangan kontrol diri yaitu antara lain tidak bisa menentukan tujuan atau menentukan tujuan yang tidak mungkin dan menyebabkan seseorang kehilangan kendali dengan tidak memperhatikan perilakunya sehingga seseorang akan mengalami stres dan merasa lemah.

Dari uraian hasil wawancara tersebut menunjukkan bahwa kenakalan remaja juga dapat di gambarkan sebagai kegagalan untuk mengembangkan kontrol diri yang cukup dalam hal tingkah laku. Hasil penelitian yang dilakukan oleh Kartono (2013) menyatakan bahwa salah satu faktor penting penyebab timbulnya kenakalan remaja pada umumnya kurang memiliki kontrol diri atau justru menyalahgunakan kontrol diri tersebut dan suka menegakkan standart tingkah laku sendiri, disamping meremehkan keberadaan orang lain.

Fenomena-fenomena akibat dari kontrol diri rendah banyak terjadi dalam kehidupan masyarakat. Hilangnya kendali diri dapat menimbulkan berbagai akibat misalnya kenakalan remaja. Pada sebuah penelitian, ditemukan adanya dukungan yang diberikan bagi pendapat bahwa kontrol diri memainkan peran penting dalam kenakalan remaja Feldman \& Wenberger (dalam Nurmala, 2007). Kenakalan remaja juga dapat di gambarkan sebagai kegagalan untuk mengembangkan kontrol diri yang cukup dalam hal tingkah laku. Kebanyakan orang muda telah mempelajari perbedaan tingkah laku yang dapat di terima dan tingkah laku yang tidak dapat diterima, namun remaja yang melakukan kenakalan tidak mengenali hal ini. Mereka mungkin gagal membedakan tingkah laku yang dapat diterima atau mungkin mereka sebenarnya sudah mengetahui kontrol diri 
tersebut namun gagal mengembangkan kontrol yang memadai untuk membimbing tingkah laku mereka Mischel \& Gilligan (dalam Santrock, 2003).

Setiap individu memiliki suatu mekanisme yang dapat membantu mengatur dan mengarahkan perilaku yaitu kontrol diri. Seseorang yang bermasalah dengan pengendalian diri biasanya berasal dari emosi (rasa marah), rasa marah sendiri dapat berasal dari masalah pekerjaan, waktu luang (tidak ada pekerjaan), keadilan ataupun situasi sosial yang terkubur, Wahyudi (dalam Gunarsa, 2003). Sebagai salah satu sifat kepribadian, kontrol diri pada satu individu dengan individu yang lain tidaklah sama. Ada individu yang memiliki kontrol diri yang tinggi dan ada individu yang memiliki kontrol diri yang rendah. Individu yang memiliki kontrol diri tinggi mampu mengubah kejadian dan menjadi agen utama dalam mengarahkan dan mengatur perilaku yang membawa kepada konsekuensi positif.

Untuk memahami kenakalan remaja, kita harus mengkaji berbagai aspek yang berbeda dalam perkembangan kontrol diri, sebagai contoh, penundaan pemenuhan kebutuhan (delay of gratification) dan standart tingkah laku yang ditentukan sendiri. Kegagalan menunda pemenuhan kebutuhan berhubungan dengan tingkah laku mencontek atau curang atau ketiadaan tanggung jawab sosial. Hal ini sering di temui pada remaja yang melakukan kenakalan remaja, Mischel \& Gilligan (dalam Santrock, 2003). Liebert dalam (Nurmala, 2007), mendefinisikan kontrol diri sebagai kemampuan melawan godaan dan kemampuan menunda kepuasaan. Kemampuan melawan godaan adalah kemampuan individu untuk mengikuti aturan-aturan sosial meskipun dalam keadaan terdesak. Bentuk kontrol diri melibatkan kemampuan menunda kepuasan untuk mencapai hasil atau tujuan yang diinginkan.

\section{KAJIAN PUSTAKA}

Remaja

Menurut Piaget (dalam Hurlock, 2002) secara psikologis, masa remaja adalah usia di mana individu berintegrasi dengan masyarakat dewasa, usia dimana anak tidak lagi merasa di bawah tingkat orang- orang yang lebih tua melainkan berada dalam tingkatan yang sama, sekurang- kurangnya dalam masalah hak. Integrasi dalam masyarakat (dewasa) mempunyai banyak aspek efektif, kurang lebih berhubungan dengan masa puber. Termasuk juga perubahan intelektual 
yang mencolok. Transformasi intelektual yang khas dari cara berpikir remaja ini memungkinkannya untuk mencapai integrasi dalam hubungan sosial orang dewasa, yang kenyataannya merupakan ciri khas yang umum dari periode perkembangan ini.

Menurut Monks (2006) batasan usia remaja adalah masa di antara 12- 21 tahun dengan perincian 12- 15 tahun masa remaja awal, 15- 18 tahun masa remaja pertengahan, dan 18- 21 tahun masa remaja akhir. Sementara Hurlock (2002) membagi masa remaja menjadi masa remaja awal (13 hingga 16 atau 17 tahun) dan masa remaja akhir (16 atau 17 tahun hingga 18 tahun) masa remaja awal dan akhir dibedakan oleh Hurlock, karena pada masa remaja akhir individu telah mencapai transisi perkembangan yang lebih mendekati masa dewasa.

Hurlock (1999) menyebutkan bahwa remaja memiliki ciri-ciri sebagai berikut,

1. Masa remaja sebagai periode yang penting

2. Masa remaja sebagai periode peralihan

3. Masa remaja sebagai periode perubahan

4. Masa remaja sebagai usia bermasalah

5. Masa remaja sebagai masa mencari identitas
6. Masa remaja sebagai usia yang menimbulkan ketakutan.

7. Masa remaja sebagai masa yang tidak realistik

8. Masa remaja sebagai ambang masa dewasa

\section{Kenakalan Remaja}

Istilah kenakalan remaja merujuk pada berbagai perilaku, mulai dari perilaku yang tidak dapat diterima secara sosial, seperti berbuat onar di sekolah, status pelanggaran seperti melarikan diri dari rumah, hingga tindakan kriminal seperti pencurian (Santrock, 2007). Untuk keperluan hukum, dibuat pembedaan antara indeks pelanggaran dan status pelanggaran sebagai berikut :

1. Indeks pelanggaran (index offenses), yakni tindakan kriminal yang dilakukan oleh remaja atau pun orang dewasa. Tindakan kriminal tersebut meliputi perampokan, serangan yang menimbulkan kerugian, pemerkosaan, dan pembunuhan.

2. Status pelanggaran (offenses status), misalnya melarikan diri, membolos dari sekolah, mengonsumsi minuman keras meskipun masih dibawah umur, melakukan hubungan seksual, dan tidak dapat dikendalikan, merupakan tindakan yang kurang serius. Tindakan ini ditampilkan oleh anak-anak muda 
di bawah umur, yang di klasifikasikan sebagai pelanggar remaja. Studi yang dilakukan baru-baru ini menemukan bahwa status pelanggaran cenderung meningkat di masa remaja, Bongers dkk, 2004 (dalam Santrock, 2007).

Menurut Santrock (1996), ada beberapa faktor-faktor yang mempengaruhi kenakalan remaja, yaitu :

1. Identitas

2. Kontrol diri

3. Usia

4. Jenis kelamin

5. Harapan terhadap pendidikan dan nilai-nilai di sekolah

6. Proses keluarga

7. Pengaruh teman sebaya

8. kelas sosial ekonomi

9. Kualitas lingkungan sekitar tempat tinggal

Jansen dalam (Sarwono, 2002) membagi kenakalan remaja menjadi empat aspek yaitu :

1. Kenakalan yang menimbulkan korban fisik pada orang lain seperti perkelahian, pemerkosaan, perampokan, pembunuhan, dan lainlain.

2. Kenakalan yang menimbulkan korban materi seperti perusakan, pencurian, pencopetan, pemerasan dan lain-lain.
3. Kenakalan sosial yang tidak menimbulkan korban dipihak orang lain seperti pelacuran, penyalahgunaan obat, dan hubungan seks bebas.

4. Kenakalan yang melawan status anak sebagai pelajar dengan cara membolos, kabur dari rumah, dan membantah perintah orang tua.

Menurut Kartono, (2006), jenis perilaku kenakalan remaja adalah sebagai berikut:

1. Kebut-kebutan di jalan raya yang dapat menggangu keamanan lalu lintas dan dapat membahayakan jiwa sendiri atau orang lain.

2. Perilaku ugal-ugalan, berandalan, urakan yang mengacau ketentraman masyarakat sekitarnya, tingkah laku ini bersumber pada kelebihan energi dan dorongan primitive yang tidak terkendali serta kesukaan menteror lingkungan.

3. Perkelahian antar gang, antar kelompok, antar sekolah, antar suku, sehingga kadang-kadang membawa korban jiwa.

4. Membolos sekolah lalu bergelandangan di sepanjang jalan, atau bersembunyi di tempat-tempar terpencil sambil melakukan bermacam-macam eksperimen kedurjanaan dan tindak asusila. 
5. Kriminalitas anak remaja dan adolesen, antara lain perbuatan mengancam, intimidasi, pemerasan, maling, mencuri, mencopet, merampas dan melakukan pembunuhan mengambil barang milik korbannya serta pelanggaran lainnya.

6. Berpesta pora dengan mabukmabukan, melakukan hubungan seks bebas atau orgi (mabuk-mabukan hebat dan menimbulkan keadaan kacau balau) yang mengganggu lingkungan

7. Perkosaan, agresivitas seksual dan pembunuhan dengan motif seksual, atau di dorong oleh reaksi-reaksi kompesatoris atau perasaan inferior, menuntut pengakuan diri, depresi hebat, rasa kesunyian, emosi balas dendam, kecemasan ditolak cintanya oleh seorang wanita dan lain-lain.

8. Kecenderungan ketagihan bahan narkotika yang erat kaitannya dengan tindak kejahatan.

9. Tindakan immoral seksual secara terang-terangan

\section{Kontrol Diri}

Kontrol diri berkaitan dengan bagaimana individu mengendalikan emosi serta dorongan-dorongan dari dalam dirinya (Hurlock, 1997). Synder dan Gangestad (dalam Soejanto, 2005) menganggap bahwa konsep mengenai kontrol diri secara langsung sangat relevan untuk melihat hubungan antara pribadi dengan lingkungan masyarakat dalam megatur kesan masyarakat yang sesuai dengan isyarat situasional dalam bersikap dan berpendirian yang efektif. Goldfired dan Merbaum (dalam Gunarsa, 2012) mendefinisikan kontrol diri sebagai proses yang menjadikan individu sebagai agen utama dalam membimbing, mengatur, dan mengarahkan bentukbentuk perilaku yang dapat membawa individu kearah konsekuensi positif. Kontrol diri ini menyangkut seberapa kuat seseorang memegang nilai dan kepercayaan untuk dijadikan acuan ketika ia bertindak atau mengambil suatu keputusan. Peningkatan kemampuan mengontrol diri menurut (Sudarsono, 2004) dapat membuat seseorang menjadi berkurang emosinya dan dapat berbuat lebih baik. Pemahaman terhadap diri sendiri dan mampu mengenali bagaimana perasaan-perasaan sendiri dan alasannya. Juga merupakan benteng pertahanan yang mencegah kita dari kesalahan-kesalahan dan terlibat dalam masalah.

Menurut Averilln (dalam Nurmala, 2007) ada tiga aspek dalam kontrol diri yaitu: 
1. Kontrol Perilaku (Behavioral Control) yaitu kemampuan untuk memodifikasi suatu keadaan yang tidak menyenangkan, kemampuan ini terdiri dari kemampuan untuk mengontrol perilaku yaitu kemampuan menentukan siapa yang mengendalikan situasi. Dimana individu yang kontrol dirinya, bila tidak mampu maka individu akan menggunakan sumber eksternal untuk mengatasinya.

2. Aspek ini didefinisikan sebagai kesiapan suatu respon yang dapat secara langsung mempengaruhi suatu keadaan yang tidak menyenangkan. Yaitu kemampuan untuk memodifikasi stimulus. Kemampuan untuk mengatur stimulus merupakan untuk mengetahui bagaimana dan kapan suatu stimulus yang tidak dikehendaki dapat diharapkan. Ada beberapa cara yang dapat digunakan yaitu : mencegah atau menjauhi stimulus, menepatkan waktu diantara rangkaian stimulus yang sedang berlangsung, menghentikan stimulus sebelum waktunya berakhir.

\section{Kontrol Kognitif (Cognitif Control)}

Yaitu kemampuan individu untuk mengolah informasi yang tidak diinginkan dengan cara menginterpretasi, menilai untuk memadukan suatu kejadian dalam suatu kerangka kognitif sebagai adaptasi psikologi atau mengurangi tekanan.

4. Aspek ini juga terdiri dari dua komponen yaitu : memperoleh informasi dan melakukan penilaian. Informasi yang dimiliki mengenai suatu keadaan yang tidak menyenangkan, seseorang dapat mengantisipasi keadaan tersebut dengan berbagai pertimbangan, melakukan penilaian berarti seseorang berusaha untuk menilai dann menafsirkan suatu keadaan atau peristiwa.

5. Kontrol Pengambilan Keputusan (Decisional Control), yaitu kemampuan untuk memilih suatu tindakan berdasarkan suatu yang diyakini atau disetujui. Kontrol pribadi dalam menentukan pilihan akan berfungsi baik dengan adanya suatu kesempatan, kebebasan atau kemungkinan pada diri individu untuk memilih beberapa hal yang saling memberatkan, maka aspek yang diukur adalah kemampuan mengontrol perilaku, dan kemampuan mengambil keputusan.

Faktor-faktor yang mempengaruhi kontrol diri diantaranya yaitu : 
1. Faktor internal, yakni faktor usia dan kematangan (Hurlock, 1973).

2. Faktor eksternal, yakni lingkungan dan pendidikan (Sarafino, 2000)

Nelson (dalam Agustiani, 2006) menemukakan faktor-faktor yang mempengaruhi kontrol diri pada seseorang adalah :

1. Orangtua

2. Faktor budaya

3. Faktor kognitif

\section{METODE PENELITIAN}

Penelitian ini menggunakan pendekatan kuantitatif jenis deskriptif dan asosiatif. Penelitian ini merupakan penelitian deskriptif karena bertujuan membuat pencanderaan/lukisan/deskripsi mengenai fakta-fakta dan sifat-sifat suatu populasi atau daerah tertentu secara sistematik, faktual dan teliti.

\section{Populasi dan Sampel Penelitian}

Populasi dalam penelitian ini adalah para remaja laki-laki di kelurahan Mabar Hilir sebanyak 400 orang. Adapun teknik yang digunakan dalam penelitian ini adalah random sampling yang artinya subjek penelitian dipilih secara acak, dan kemudian diambil $10 \%$ dari jumlah sampel remaja laki-laki 400 orang, maka subjek yang dijadikan sampel sebanyak 40 orang remaja laki-laki.

\section{Teknik Pengumpulan Data}

Pengumpulan data pada penelitian ini menggunakan metode skala. Skala psikologis yang digunakan dalam penelitian ini berjumlah dua skala, yaitu skala kontrol diri dan skala kenakalan remaja. Kedua skala ini menggunakan skala model Likert dengan empat pilihan respon, yaitu SS (sangat setuju), S (setuju), TS (tidak setuju), dan STS (sangat tidak setuju). Respon dari item favourable akan mamiliki bobot nilai empat untuk respon sangat setuju, tiga untuk respon setuju, dua untuk respon tidak setuju, dan satu untuk respon sangat tidak setuju. Respon dari item unfavourable akan memiliki bobot nilai satu untuk respon sangat setuju, dua untuk respon setuju, tiga untuk respon tidak setuju dan empat untuk respon sangat tidak setuju.

\section{Teknik Analisis Data}

Metode analisis yang digunakan dalam penelitian ini adalah teknik korelasi product moment dari Karl Pearson. Formula teknik product moment dimaksud :

$$
\mathrm{r}_{\mathrm{xy}}=\frac{\sum \mathrm{XY}-\frac{\left(\sum \mathrm{X}\right)\left(\sum \mathrm{Y}\right)}{\mathrm{N}}}{\sqrt{\left(\left(\sum \mathrm{X}^{2}\right)-\frac{\left(\sum \mathrm{X}\right)^{2}}{\mathrm{~N}}\right)\left(\left(\sum \mathrm{Y}^{2}\right)-\frac{\left(\sum \mathrm{Y}\right)^{2}}{\mathrm{~N}}\right)}}
$$

Keterangan:

$\mathrm{r}_{\mathrm{xy}} \quad$ : koefisien korelasi butir dengan total $\sum X Y$ : jumlah dari hasil perkalian antara setiap $\mathrm{X}$ dengan setiap $\mathrm{Y}$ 
$\sum X \quad$ : jumlah skor keseluruhan butir tiap subjek

$\sum \mathrm{Y}$ :jumlah skor kesdeluruhan item pada subjek

$\sum \mathrm{X}^{2} \quad$ : jumlah kwadrat skor $\mathrm{X}$

$\sum_{N} \quad$ : jumlah kwadrat skor $\mathrm{Y}$

Dahulu dilakukan uji asumsi terhadap data-data penelitian yaitu : uji normalitas, yaitu untuk mengetahui apakah distribusi data penelitian setiap masing-masing variabel telah menyebar secara normal, dan uji linieritas, yaitu untuk mengetahui apakah variabel bebas memiliki hubungan linier dengan variabel terikatnya.

\section{HASIL DAN PEMBAHASAN}

\section{Uji Asumsi}

\section{a. Uji Normalitas Sebaran}

Hasil uji normalitas yang dilakukan dengan menggunakan teknik Kolmogorov-Smirnov terhadap variabel kontrol diri menunjukkan hasil yaitu nilai $P$ sebesar $0.135(p>0,05)$ yang berarti sebaran item variabel kontrol diri berdistribusi secara normal. Hasil yang sama untuk uji normalitas yang dilakukan dengan mengggunakan teknik Kolmogorov-Smirnov terhadap variabel kenakalan remaja menunjukkan hasil yaitu nilai $\mathrm{P}$ sebesar $0.080(\mathrm{p}>0,05)$ yang berarti sebaran item variabel kenakalan remaja berdistribusi secara normal.
Tabel 1. Rangkuman Hasil perhitungan Uji Normalitas Sebaran

\begin{tabular}{|l|l|l|l|l|l|}
\hline Variabel & Mean & K-S & SD & $\begin{array}{l}\mathbf{P} \\
\mathbf{( p > 0} \\
\mathbf{0 5})\end{array}$ & $\begin{array}{l}\text { Keteran } \\
\text { gan }\end{array}$ \\
\hline $\begin{array}{l}\text { Kontrol } \\
\text { Diri }\end{array}$ & 76,65 & 0,135 & $\begin{array}{l}14,2 \\
59\end{array}$ & $\begin{array}{l}0.06 \\
6\end{array}$ & Normal \\
\hline $\begin{array}{l}\text { Kenakala } \\
\text { n Remaja }\end{array}$ & 92,45 & 0.080 & $\begin{array}{l}18,2 \\
07\end{array}$ & $\begin{array}{l}0.20 \\
0\end{array}$ & Normal \\
\hline
\end{tabular}

Keterangan:

$\begin{array}{ll}\text { Mean } & =\text { Nilai rata-rata } \\ \text { K-S } & =\text { Kolmologrov Smimov } \\ \text { SD } & =\text { Standar Deviasi } \\ \mathrm{P} & =\text { Signifikansi }\end{array}$

\section{b. Uji Homogenitas Varians}

Berdasarkan uji linieritas, dapat diketahui apakah variabel bebas dengan variabel terikat dalam penelitian ini dapat atau tidak dianalisi secara korelasional. Hasil analisis menunjukkan bahwa antara variabel kontrol diri mempunyai hubungan yang linier dengan variabel kenakalan remaja. Sebagai kriterianya apa bila bilangan signifikan $\mathrm{p}<0.05$ maka dapat dinyatakan mempunyai derajat hubungan yang linier (Hadi. 1995). Koefisien hubungan tersebut dapat dilihat pada table di bawah ini:

Tabel 2. Rangkuman Hasil Perhitungan Uji Linieritas Varians

\begin{tabular}{|c|c|c|c|c|}
\hline $\begin{array}{c}\text { Korelasiona } \\
1\end{array}$ & $\mathrm{~F}$ & $\mathrm{P}$ Beda & Ket & $\begin{array}{c}\text { Korelasio } \\
\text { nal }\end{array}$ \\
\hline $\mathrm{X}-\mathrm{Y}$ & 6,097 & 0.04 & Linier & $\mathrm{X}-\mathrm{Y}$ \\
\hline
\end{tabular}

\section{Hasil Perhitungan Analisis Korelasi Product Moment}

Berdasarkan hasil perhitungan Analisis Korelasi Product Moment, dapat diketahui bahwa terdapat hubungan 
negatif yang sangat signifikan antara kontrol diri dengan kenakalan remaja. Artinya semakin rendah kontrol diri maka semakin tinggi kenakalan remaja, sebaliknya semakin tinggi kontrol diri maka, semakin rendah kenakalan remaja. Hasil ini dibuktikan dengan koefisien korelasi $r_{x y}=0.421, \mathrm{p}=0.04 \mathrm{p}<0.05$, dengan demikian maka hipotesis yang diajukan, dinyatakan diterima. Kontrol diri memberikan pengaruh terhadap kenakalan remaja sebesar $17.7 \%$. Hal ini dibuktikan dengan Koefisien Determinan X terhadap Y sebesar 17.7.

Tabel 3.Rangkuman Hasil Analisis Korelasi Product Moment

\begin{tabular}{|c|c|l|c|c|c|}
\hline Statistik & $\begin{array}{c}\text { Koefisien } \\
\left(r_{x y}\right)\end{array}$ & $\begin{array}{l}\text { Koef. } \\
\text { Det I } \\
r^{2}\end{array}$ & P & BE\% & Ket \\
\hline$X-Y$ & 0.421 & 0,177 & 0.04 & 17.7 & SS \\
\hline
\end{tabular}

Keterangan :

$\mathrm{X} \quad=$ Kontrol Diri

$\mathrm{Y} \quad=$ Kenakalan Remaja

$r_{x y}=$ Koefisien korelasi antara variabel $\mathrm{X}$

dengan $\mathrm{Y}$

$r^{2}=$ Koefisien Determinan $\mathrm{X}$ terhadap $\mathrm{Y}$

$\mathrm{P} \quad=$ Signifikansi

$\mathrm{BE} \%=$ Bobot sumbangan efektif $\mathrm{X}$ terhadap $\mathrm{Y}$ dalam persen

SS = Sangat Signifikan

Ini berarti masih terdapat $82.3 \%$

pengaruh dari faktor lain terhadap kenakalan remaja, diantaranya adalah faktor identitas, usia, jenis kelamin, harapan terhadap pendidikan dan nilainilai di sekolah, proses keluarga, pengaruh teman sebaya, kelas sosial ekonomi dan kualitas lingkungan sekitar tempat tinggal. Faktor yang berhubungan dengan hal-hal yang berwujud maupun tidak berwujud. Faktor yang dapat dijadikan bahan untuk mencapai tujuan organisasi

Tabel 4. Statistik Induk

\begin{tabular}{|c|c|c|c|}
\hline Variabel & $N$ & Mean & $S D$ \\
\hline $\mathrm{X}$ & 40 & 76.65 & 14.259 \\
\hline $\mathrm{Y}$ & 40 & 92.45 & 18.207 \\
\hline
\end{tabular}

Keterangan:

$\mathrm{X}=$ Kontrol Diri

$\mathrm{Y} \quad=$ Kenakalan Remaja

$\mathrm{N} \quad=$ Jumlah Subjek

Rerata = Nilai rata-rata

SD = Standar Deviasi

3. Hasil Perhitungan Mean

\section{Hipotetik dan Mean Empirik}

\section{a. Mean Hipotetik}

Untuk variabel kontrol diri, jumlah butir yang dipakai adalah sebanyak 30 butir yang diformat dengan skala Likert dalam 4 jawaban, maka mean hipotetiknya adalah $\{(31 \times 1)+(31 \times 4$ ) $\}: 2=77,5$. Kemudian untuk variabel kenakalan remja, jumlah item yang di pakai adalah sebanyak 24 butir yang juga diformat dengan skala Likert dalam 4 jawaban, maka mean hipotetiknya adalah $\{(33 \times 1)+(33 \times 4)\}: 2=82,5$.

\section{b. Mean Empirik}

Berdasarkan analisis data, seperti yang terlihat dari analisis uji normalitas sebaran dan statistic induk di ketahui bahwa, mean empirik perilaku kontrol diri sebesar 76.65 dengan bilangan SD 
sebesar 14.259 sedangkan untuk variabel kenakalan remaja nilai rata-rata empiriknya adalah 92,45 dengan bilangan SD sebesar 18.207.

\section{c. Kriteria}

Dalam upaya mengetahui bagaimana kontrol diri dan kenakalan remaja, maka perlu dibandingkan antara mean/nilai rata-rata empirik dengan mean/nilai rata-rata hipotetik dengan memperhatikan besarnya bilangan SD dari masing-masing variabel. Dari besarnya bilangan simpangan baku SD tersebut maka, untuk variable kontrol diri. Apabila mean hipotetik < mean empiric dimana selisihnya melebihi bilangan satu SD, maka subjek penelitian memiliki control diri yang positif, sedangkan apabila mean hipotetik > mean empiric dimana selisihnya melebihi satu SD maka subjek penelitian memiliki kontrol diri yang negatif.

Selanjutnya untuk variabel kenakalan remaja, apabila mean/nilai rata hipotetik < mean/nilai rata-rata empirik, dimana selisihnya melebihi bilangan satu SD, maka subjek penelitian memiliki kenakalan remaja yang tinggi, sedangkan apabila mean hipotetik > mean empiric dimana selisihnya melebihi bilangan satu SD, maka subjek penelitian memiliki kenakalan remaja yang rendah.
Gambaran selengkapnya mengenai perbandingan mean/nilai rata-rata hipotetik dengan mean/nilai rata-rata empiric dapat dilihat pada tabel di bawah ini.

Tabel 4. Hasil Perhitungan Nilai Rata-rata Hipotetik dan Nilai Rata-rata Empirik

\begin{tabular}{|l|c|c|c|c|}
\hline \multirow{2}{*}{ Variabel } & \multicolumn{2}{|c|}{ Nilai Rata-Rata } & \multirow{2}{*}{ SD } & \multirow{2}{*}{ KET } \\
\cline { 2 - 3 } & Hipotetik & Empirik & & \\
\hline Kontrol Diri & 77,5 & 76,65 & 14,259 & Rendah \\
\hline $\begin{array}{l}\text { Kenakalan } \\
\text { Remaja }\end{array}$ & 82,5 & 92,45 & 18,207 & Tinggi \\
\hline
\end{tabular}

Berdasarkan perbandingan kedua nilai rata-rata di atas ( mean hipotetik dan mean empirik), maka dapat dinyatakan bahwa kontrol diri tergolong rendah dan kenakalan remaja (subjek penelitian) tergolong tinggi.

Berdasarkan hasil perhitungan Analisis Korelasi Product Moment, dapat diketahui bahwa terdapat hubungan negative yang sangat signifikan antara kontrol diri dengan kenakalan remaja. Artinya semakin rendah kontrol diri maka, semakin tinggi pula kenakalan remaja, sebaliknya semakin tinggi kontrol diri maka, semakin rendah kenakalan remaja. Hasil ini dibuktikan dengan koefisien korelasi $r_{x y}=0,421$ dengan $\mathrm{p}=$ $0,04, p<0.05$ sesuai dengan kriteria yang telah ditentukan, jika nilai signifikansi yang diperoleh $\mathrm{p}<0,05$ maka hasil penelitian dinyatakan sangat signifikan. Berdasarkan hasil penelitian ini, maka 
dapat dinyatakan bahwa semakin rendah kontrol diri maka, semakin tinggi kenakalan remaja, maka hipotesis yang telah diajukan dalam penelitian ini, dinyatakan diterima.

Kenakalan remaja sebagai perilaku yang melanggar hukum atau kejahatan yang biasanya dilakukan oleh anak remaja yang berusia 13-18 tahun, karena pada usia saat itu remaja tersebut mencari masa identitas dimana penyesuaian diri dengan kelompok lebih penting daripada bersikap individual, serta masa remaja sebagai usia yang menimbulkan ketakutan maksudnya disini anggapan stereotype bahwa remaja adalah anakanak yang tidak dapat dipercaya hal seperti ini yang cenderung dan berperilaku merusak dirinya, dan perkembangan moral remaja tersebut lebih mengikuti apa yang harus dikatakan oleh kelompoknya sehingga perilakunya harus membentuk apa yang harus dan apa yang sesuai agar bisa diterima dengan kelompoknya.

Kontrol diri Harter (dalam Muharsih, 2008), menyatakan dalam diri seseorang terdapat suatu sistem pengaturan diri (self regulation) yang memusatkan perhatian pada kontrol diri (self control). Proses pengontrolan diri menjelaskan bagaimana diri mengatur dan mengontrol perilaku dalam menjalani kehidupan sesuai dengan kemampuan dalam individu dalam mengatur perilaku. Individu yang mengatur perilakunya dengan baik, maka individu dapat menjalani kehidupan dengan baik.

Selanjutnya berdasarkan koefisien determinan $\left(r^{2}\right)$ dan hubungan antara kontrol diri dengan kenakalan remaja yaitu sebesar $r^{2}=0,177$ ini menunjukkan bahwa kenakalan remaja di pengaruhi oleh kontrol diri sebesar 17,7\% dan $82,3 \%$ dipengaruhi oleh faktor lain yang tidak diteliti dalam penelitian ini faktor lain tersebut diantaranya, adalah faktor identitas, usia, jenis kelamin, harapan terhadap pendidikan dan nilainilai di sekolah, proses keluarga, pengaruh teman sebaya, kelas sosial ekonomi dan kualitas lingkungan sekitar tempat tinggal

Secara umum hasil penelitian ini menyatakan bahwa kontrol diri dengan kenakalan remaja di kelurahan Mabar Hilir tergolong tinggi dimana nilai ratarata empirik diatas nilai rata-rata hipotetik dalam kurva normal. Nilai ratarata empirik kontrol diri $=76,65$ sedangkan nilai rata-rata hipotetiknya sebesar $=77,5$ kemudian nilai rata-rata empirik kenakalan remaja $=92,45$ 
sedangkan nilai rata-rata hipotetiknya sebesar $=82,5$.

\section{PENUTUP}

\section{Simpulan}

Berdasarkan hasil perhitungan korelasi $r$ Product Moment diketahui bahwa terdapat hubungan negatif antara kontrol diri dengan kenakalan remaja pada remaja di kelurahan Mabar Hilir ( $r_{x y}=0.421$ dengan $\mathrm{p}=0,04, \mathrm{p}<0.05$ sesuai dengan kriteria yang telah ditentukan, jika nilai signifikansi yang diperoleh $\mathrm{p}<0,05$ maka hasil penelitian dinyatakan sangat signifikan.

Berdasarkan koefisien determinan $\left(r^{2}\right)$ dari hubungan diatas adalah sebesar $r^{2}=0,177$ ini menunjukkan bahwa kenakalan remaja di pengaruhi oleh kontrol diri sebesar $17,7 \%$ dan $82,3 \%$ dipengaruhi oleh faktor lain yang tidak diteliti dalam penelitian ini.

Secara umum hasil penelitian ini menyatakan bahwa kontrol diri dengan kenakalan remaja di kelurahan Mabar Hilir tergolong tinggi dimana nilai ratarata empirik diatas nilai rata-rata hipotetik dalam kurva normal. Nilai ratarata empirik kontrol diri $=76,65$ sedangkan nilai rata-rata hipotetiknya sebesar $=77,5$ kemudian nilai rata-rata empirik kenakalan remaja $=92,45$ sedangkan nilai rata-rata hipotetiknya sebesar $=82,5$

\section{Saran}

Disarankan kepada para remaja agar dapat menghindari perilaku kenakalan remaja, mengingat perilaku kenakalan remaja ini memiliki dampak negatif yang lebih banyak, yakni membuang-buang uang untuk hal yang tidak penting. Dalam upaya menurunkan tingginya perilaku kenakalan remaja, maka disarankan kepada para remaja agar terus meningkatkan kontrol diri seperti yang selama ini dimiliki, misalnya dengan menerapkan disiplin diri yang lebih tinggi dan lebih religius, misalnya di kelurahan Mabar Hilir setiap Masjid di bentuk panitia Remaja Masjid untuk membentuk karakter religius agar lebih bisa disiplin, diadakan penyuluhan apa dampak atau bahaya yang terjadi apabila remaja tersebut mengalami kenakalan remaja.

Melihat banyaknya remaja di kelurahan Mabar Hilir yang mengalami kenakalan remaja, maka diharapkan oleh pihak kelurahan untuk memperhatikan dan mengayomi serta mengajak semua orangtua untuk bisa mengawasi anaknya agar tidak terjerumus dalam berperilaku kenakalan dan memberikan ruang gerak atau wadah kepada anaknya agar bisa 
mengembangkan kreatifitas, misalnya membentuk kelompok olahraga, mengadakan keterampilan-keterampilan supaya si anak tidak mempunyai waktu untuk melakukan hal-hal yang tidak baik. Disarankan kepada peneliti selanjutnya yang berminat melanjutkan penelitian ini diharapkan mampu melihat peranan dari faktor lain terhadap perilaku kenakalan remaja, diantaranya adalah faktor identitas, kontrol diri, usia, jenis kelamin, harapan terhadap pendidikan dan nilainilai di sekolah, proses keluarga, pengaruh teman sebaya, kelas sosial ekonomi dan kualitas lingkungan sekitar tempat tinggal. Diharapkan dengan dilakukannya penelitian lanjutan, dapat diperoleh hasil yang lebih lengkap.

\section{DAFTAR PUSTAKA}

Azwar, S. 1998. Metodologi penelitian. Yogyakarta: Pustaka Pelajar Offset 2002. Penyusunan skala psikologi. Yogyakarta: Pustaka Pelajar Offset

Agustiani, H. 2006. Psikologi Perkembangan Pendekatan Ekologi Kaitannya dengan Konsep Diri dan Penyesuaiian Diri pada Remaja. Jakarta: PT. Refika Aditama

Calhoun, J.F. dan Acocella, J.R. 1990. Psychology of Adjusment and
Human Relationship, New York: McGraw-Hill, Inc

Chaplin, J.P. 2006. Kamus Lengkap Psikologi, Jakarta: Rieheke Cipta

Dariyo, Agoes. 2003. Perkembangan Remaja, Jakarta: Ghalia Indonesia

Fakih, M. 2006. Analisis Gender dan Transformasi Sosial, Yogyakarta: Pustaka

Gunarsa, S.D. 2003. Psikologi Remaja (cetakan kelima belas), Yogyakarta: Jalasutra

Gunarsa, Y.S. 2013. Psikologi Remaja, Jakarta: Libri

Hadi, Sutrisno. 2000. Statistik, jilid 2 Yogyakarta: Andi

Hurlock, E.B. 1980. Psikologi Perkembangan, Jakarta: Erlangga

Hurlock, E.B. 1990. Psikologi Perkembangan Edisi 5, Jakarta: Erlangga

1991. Psikologi Perkembangan: Suatu Pendekatan Sepanjang Rentan Kehidupan, Jakarta: Erlangga

1997. Psikologi Perkembangan: Suatu Pendekatan Sepanjang Rentan Kehidupan edisi ke lima (terjemahan Istiwi dayanti dan Soejarwo). Jakarta: Erlangga 
1999. Perkembangan

Anak, Jakarta: Erlangga

Kartono, K. 2006. Patologi Sosial 2 Kenakalan Remaja, Jakarta: PT Raja Grafindo Persada

2012. Patologi Sosial 2 Gangguan-gangguan Kejiwaan, Jakarta: PT Raja Grafindo Persada

2013. Patologi Sosial 2 Kenakalan Remaja, Jakarta: Rajawali Pers

Monks, F.J.dkk. 2006. Psikologi Perkembangan Pengantar dalam Berbagai Bagiannya, Yogyakarta: Gadjah Mada University Press.

Nurmala, S. 2007. Hubungan antara Kematangan Beragama dengan Kontrol Diri pada Siswa Madrasah Labuhan Bilik, Skripsi: Fakultas Psikologi Universitas Medan Area

Sarafino, E.P. 2000. Health Psychology : Biopsychosocial Interactions, 3Ed, Chapter 3, Stress-Its Meaning, Impact, and Sources. John Wiley and Sons, New York

Santrock, J.W. 2002. Life-Span Development, Jakarta: Erlangga ,dkk. 2003. Adolesence Perkembangan Remaja, Jakarta: Erlangga 2007. Remaja Edisi kell Jilid 2, Jakarta: Erlangga
Sarwono, S.W. 2000. Remaja dan Masalah-masalahnya, Jakarta: Gunung Mulia 2011. Psikologi Remaja, Jakarta: Rajawali Pers

Sinisuka, E. 1978. Masalah-masalah Kenakalan Remaja \& Penanggulangannya

Soejanto, A. 2005. Psikologi Perkembangan, Jakarta: Riheke Cipta

Sudarsono. 2004. Kenakalan Remaja, Jakarta: Riheke Cipta

1993. Etika Islam tentang Kenakalan Remaja, Jakarta: Riheke Cipta

Sugiyono, K. 2004. Pengantar Sosiologi (Edisi Revisi), Jakarta: Lembaga Penerbit Fakultas Ekonomi Universitas Indonesia

Umar, H. 2005. Riset Sumber Daya Manusia dalam Organisasi, Jakarta: PT. Gramedia Pustaka Utama. 